\title{
Claudia Groß*
}

\section{Spiritual Cleansing: A Case Study on how Spirituality Can Be Mis/used by a Company}

\author{
Amway is "simply a just, a just system!" (Manager)1 \\ Amway "is the most unfair thing that exists! ... I hate it" (Former distributor)
}

Organisational spirituality has gained popularity. While some authors see a spiritually fulfilling workplace as a benefit for employees and organisations alike, critical authors point out the potentially totalising effects of organisations that try to colonise employees' minds, hearts and souls. Whereas most existing critical studies are based on literature analyses and mainly refer to societal developments and how organisations are affected by them, the paper at hand provides a single case study on the organisational level. The case study allows a more detailed examination of how organisations can employ spirituality to serve organisational goals. The article identifies three aspects in which workplace spirituality can be misused: to mislead members about the nature of their work, about what an organisation can offer to its members and about the societal value of an organisation.

\section{Key words: Spirituality, critical management studies, normative control, direct selling, multi-level-marketing}

* Dr. Claudia Groß, Radboud University of Nijmegen, Institute of Management Research, Thomas van Aquinostraat 3.0.32, 6500 HK Nijmegen, The Netherlands.

E-mail: c.gross@fm.ru.nl.

$1 \quad$ This and all other quotes were translated by the author.

** I would like to thank Yvonne Benschop and two reviewers for their very helpful and constructive comments. Additionally, I would like to express my appreciation to Wenzel Matiaske and Gerd Grözinger who organised the workshop "Religion and the Organisation Man" in Dubrovnik in spring 2009 and the German DAAD which provided me with funding for participation in this valuable workshop.

Article received: January 25, 2009

Revised version accepted after double blind review: October 11, 2009.

management revue, 21(1): 60-81

ISSN (print) 0935-9915, ISSN (internet) 1861-9908
DOI 10.1688/1861-9908_mrev_2010_01_Gross

(C) Rainer Hampp Verlag, www.Hampp-Verlag.de 


\section{Introduction}

For-profit organisations in the United States increasingly use spirituality and commonly shared values such as happiness or freedom as a means of motivating employees and creating employee loyalty (Nadesan 1999). Within academic (Gull/Doh 2004; Marques 2005; Mitroff/Denton 1999) as well as non-academic literature (http://www.spiritatwork.org/), organisations and organisational research have been asked to focus on and to take better care of the spiritual needs of employees. Such claims are based on the idea that individual spirituality and organisational profit form a win-win-situation for organisations and employees alike. In contrast, critical research (partly from outside the US) has pointed out that the increased interest in organisational spirituality is a problematic development in society as companies can also misuse individual spirituality for organisational profit (Bell/Taylor 2003). Within critical research, the relationship between spirituality and organisations is regarded as a problematic one: organisations that try to win the hearts, and minds of their employees may propagate group think (Polley et al. 2005) and colonise every aspect of employees' private lives via an almost totalitarian organisational culture (Nadesan 1999).

Current critical assessments mainly analyse on the societal level why there is an increased interest in organisational spirituality (Heelas 1992). The empirical bases are mostly studies of literature, such as newspaper articles, weekly magazines and management books (Nadesan 1999), or additionally accounts of organisational practices (Bell/Taylor 2003). In contrast, this article provides a case study on the organisational level. It shows how spirituality is used and misused to "spiritualise" and extol work tasks such as recruiting new employees; organisational structures such as payment systems, and organisational goals such as higher turnover via product purchases. Based on the analysis, the article identifies three aspects in which workplace spirituality can be misused: to mislead members about the nature of their work, about what an organisation can offer to its members, and about the societal value of an organisation.

The empirical basis of the paper is a case study of the Amway Corporation in Germany. Amway is a so-called direct-selling organisation where legally independent distributors sell products such as nutritional supplements or cosmetics on a person-toperson basis. As the members are self-employed, a formal authority structure is missing. Instead, distributors are controlled via a particular organisational identity and ideology (Groß 2008; Pratt 2000a; Pratt 2000b). In the US, Amway has been categorised as a "quasi-religious corporation" (Bromley 1998) because it offers its members its own world-view and a strong community of believers (see also Biggart 1989; Pratt 2000b). In Germany, former members and consumer protectionists have criticised Amway as a cult-like organisation that binds individuals via false promises to the organisation (Sonnabend 1998). ${ }^{2}$ This article will analyse the promise of justice and its spiritual dimensions, namely that Amway is a strong community based on justice that offers a fair business opportunity for everyone and helps to create a better, i.e. fairer, society.

2 As further sources see: www.mlm-beobachter.de and www.ideologie-im-mlm.de. 
The paper proceeds as follows: First, it gives an overview of organisational spirituality and the potential problems connected with it. Second, it provides background information on Amway and the empirical study. Third, it analyses Amway internally from two sides: a harmonious perspective on spirituality and a critical one. After that, it discusses how individual spirituality is used and misused to "spiritualise" work tasks, organisational structures and organisational goals. The paper will conclude by outlining three dimensions in which organisational spirituality can be problematic.

\section{Spirituality in Organisations}

Organisational spirituality has gained increased public attention. Books about "Leading with Soul" (Bolman/Deal 1995) or "Jesus, CEO" (Jones 1995) have become bestsellers, and networks that try to enhance organisational spirituality have formed (e.g. www.spiritatwork.org/). A parallel development has taken place in academia (Bell/Taylor 2003; Gull/Doh 2004; Mitroff/Denton 1999; Nadesan 1999; Steingard 2005). The American Academy of Management Annual Meeting set up the Management, Spirituality, and Religion Interest Group at the end of 1999 and launched the Journal of Management, Spirituality \& Religion in 2004. Further academic journals have provided special issues on the topic such as the Journal of Management Education (2000) and the Journal of Organisation and Change Management (1999).

As spirituality within organisations is a relatively new field of research, current definitions are still rather vague and a broad variety of them co-exist (Brown 2003; Daniels et al. 2000). Nevertheless, two characteristics of spirituality seem to prevail within the literature: transcendence and community (Polley et al. 2005). Transcendence refers to the question of whether life has a meaning and whether there is an ultimate goal of life. The community dimension refers to the need for belonging, integrity, and brotherly love among human beings. This study follows Polley et al. (2005) in considering both dimensions as relevant to the definition of spirituality. Accordingly, organisational spirituality implies that organisations address these two dimensions and connect them to organisational goals, tasks, or values. For example, companies such as The Body Shop (Pina e Cunha et al. 2006) or Mary Kay Cosmetics (Biggart 1989; Groß 2008) claim that working for them is oriented towards higher, trans-individual values such as helping others or creating a better world.

Such claims in particular as well as the increased interest in organisational spirituality in general are remarkable as they revive the belief that work has a higher, transcendent meaning (Bell/Taylor 2003). While Weber argues in his work "The Protestant Ethic and the Spirit of Capitalism" (1920/1988) that the Puritan work ethos became secularised, i.e. work gained a value as such, now corporations claim to offer transcendence and community via working for them. Such claims belong to the context of monasteries where people work for God's sake, but can organisational profitmaking and individual spirituality fit together in modern corporations? And if yes, then how are they related to each other?

One strand of literature emphasises that organisational spirituality is a possible method of creating employee commitment and motivation as well as enhancing productivity (Gull/Doh 2004; Kolodinsky et al. 2008; Marques 2005; Mitroff/Denton 1999). According to this view, spirituality, profit-making, and individual fulfilment can 
go hand in hand with, or even support, each other. "When we can derive joy from our work, our work is no longer lifeless - it connects us with the very ground of our being, with life itself' (Gull/Doh 2004: 135). The logic behind this perspective is that human beings have spiritual needs and therefore spirituality should be part of one's own work as well as a part of the workplace. Therefore, individual and organisational spirituality are not in conflict with each other but rather the latter is a "natural" outcome of the former (Marques 2005; Mitroff/Denton 1999).

A much more critical view of the relationship between spirituality and organisational profit exists within a second strand of literature (Bell/Taylor 2003; Pina e Cunha et al. 2006). Here, spirituality in the workplace is seen as an organisational tool to minimise costs for controlling employees and to fulfil organisational profit orientation: "Somewhat paradoxically, rather than enabling liberation from the constraints of work and modernity, workplace spirituality ensures that the search for meaning is harnessed to specific organisational purposes." (Bell/Taylor 2003: 332) According to this view, based in the critical management literature (Alvesson/Willmott 2002; Rose 1990; Willmott 1993), organisational spirituality does not imply equal advantages for individuals and organisations. Rather employees' spirituality has been converted into a resource for organisations to motivate people in a cost-effective way, especially when work is fragmented and routine (Nadesan 1999; Sullivan 2006). Work tasks are mystified and for-profit organisations are presented as being "neutral grounds" which offer individuals the chance to self-actualise via working for their company (Bell/Taylor 2003; Nadesan 1999). This perspective not only includes a depoliticised view of organisations where no basic conflict of interest between employees and company exists (Nadesan 1999), but even "serves to legitimate the social order through reference to a sacred power" (Bell/Taylor 2003: 340; see also Pina e Cunha et al. 2006; Volf 1991). Accordingly, problems at the workplace are ascribed to the individuals who - via selfhelp techniques as meditation or NLP - have to adapt themselves to organisational needs as well as to transforming economic relations (Nadesan 1999). The border between private and work life is blurred, creating the risk of colonisation of the self via "holistic," "soulful", or "spiritually informed" organisations (Nadesan 1999; Pina e Cunha et al. 2006).

The above-mentioned studies observe, analyse, and account critically the increased interest in spirituality in organisations on the inter-organisational level, i.e. as a societal phenomenon (Bell/Taylor 2003; Heelas 1992; Nadesan 1999). These studies mainly rely on analysis of literature about organisational spirituality (Bell/Taylor 2003; Nadesan 1999). Complementary with the existing studies, the paper at hand provides an analysis on the organisational level. It allows a more detailed examination of how organisations "spiritualise" and extol work tasks, organisational structures and organisational goals as valuable contributions to individual fulfilment and a better society. The paper discusses why this can be a misuse of spirituality and it argues that it is necessary to take workplace spirituality somewhat critically.

Before moving on to the next section, which provides more information on the Amway Company, the approach of the paper has to be positioned against one more aspect within the existing literature: while some authors argue that spirituality and religion belong inseparably together and should be researched as such (Franz/Wong 
2005), for this study it is relevant to distinguish them (Mitroff 2003). Following Polley et al. (2005), the paper regards spirituality as a human need - a subjective and individual experience -, and religion as an institutionalised expression of spirituality (see also Ashforth/Vaidyanath 2002). This distinction is almost a precondition for researching organisational spirituality in Germany: while (civil) religion plays an important role in everyday life in the US (Bellah 1975), within Germany religion and religious beliefs are less interwoven with everyday life and are less visible in the public domain (Kaufmann 1989; Wippermann 1998). ${ }^{3}$ In contrast to the notion of religion, spirituality allows the author to research transcendence and community (Polley et al. 2005) in organisations without having a link to institutionalised forms of religions such as ecclesiastical institutions. This is a relevant aspect here because the Amway Corporation has ideals that are strongly intertwined with the Christian denomination in the US (Pratt 2000a) while this is not the case within Germany (Groß 2008).

\section{The Amway Corporation}

The Amway Corporation is - like Tupperware, Mary Kay Cosmetics, or Herbalife - a so-called direct selling organisation. Direct selling is defined "as the sale of a consumer product or service, person-to-person, away from a fixed retail location". ${ }^{4}$ Amway (www.amway.com) was founded in 1959 and is now operating in over 80 countries world-wide. The company sells a wide range of products of which approximately 450 are produced by the Amway Corporation itself. The portfolio covers mainly cosmetics, nutritional supplements, health and cleaning products. ${ }^{5}$ Amway's 3.6 million salesrepresentatives produced 6.4 billion US-dollars in wholesale prices in $2005 .{ }^{6}$

The empirical evidence for the case study presented in this article is about the German affiliate of the Amway Corporation. It was established in 1975 and had a turnover of 119 million Euros in the business year 2003/2004. At the German headquarters, the company employs an administrative staff of 200 and has around 85,000 self-employed distributors. ${ }^{7}$ Amway members often start their business while still employed at another company and drop-out rates are high. Official records are hard to find for any direct selling organisation but it is well-known that most distributors leave Amway within a year (Biggart 1989; Juth-Gavasso 1985). A study of Amway in Japan, for example, reports a turn-over rate between $60 \%$ and $70 \%$ (Croft/Woodruffe 1996: 210).

The self-employed distributors are allowed - or even encouraged - to recruit and coach new salespeople. New members form the "Downline" of their recruiter, while the latter are part of the so-called "Upline". This organisational structure belongs to one particular type of direct selling that is called multi-level-marketing or network

3 Source: Inglehart-Welzel Cultural Map of the World at www.worldvaluessurvey.org/, accessed on $3 / 23 / 2009$.

4 Source: www.dsa.org/aboutselling/what/, accessed on the 3/19/2009.

5 Source: www.amway.com/en/Product/products-10329.aspx, accessed on 3/19/2009.

6 Source: www.amway.com/en/BusOpp/business-profile-10065.aspx, accessed on 3/19/2009.

7 Source: www.amivo.de/press_room01.html, accessed on 3/19/2009. 
marketing. With the help of their Downlines' sales, distributors in multi-levelmarketing can climb up a career ladder and reach higher levels. The first levels are labelled according to the share of commission that distributors can earn back when they reach a certain turnover with their group; distributors on these levels are called for example " $3 \%$ er", " $6 \%$ er", " $18 \%$ er", or " $21 \%$ er". The next levels are labelled with metals, namely as "Silver", "Gold", and "Platinum", and then with still more precious materials such as "Ruby", "Emerald", and "Diamond" up to the "Crown-ambassador" (Schwarz/Schwarz 2001). Each of the more than 30 levels implies a higher status and more recognition in the company as well as additional commissions. Being a Platinum, for example, implies a cross commission between 2,200 and 3,000 Euro per month. It requires a monthly turnover of around 20,000 Euro of one's whole group, at this level consisting of approximately 176 people on average (Groß 2008: 193).

Officially, distributors are legally independent, i.e. they are not subject to any formal authority, and no one is legally subordinate to anyone else (Brodie et al. 2002). Nevertheless, distributors who recruit new members are responsible for teaching them how to become successful and members who have reached the level of Platinum or higher are regarded as managers. This feature, i.e. having self-employed members who are instructed, motivated, and guided by self-employed managers, minimises internal criticism: whoever has recruited another member into his or her Downline is advised by his or her own Upline not to publicly doubt the corporate policy - i.e., the commission system, the products, or the organisational culture. Recruiters try to act as a model of trust in the company as they fear that admitting problems discourages their Downline (and other distributors as well) and thus destroys their own financial basis for climbing up the ladder of success.

This common characteristic of multi-level-marketing companies (Biggart 1989) is relevant to keep in mind because the empirical study presented in the next section may seem too one-sided: it considers current members who are mainly positive about Amway and former members who have a contrary assessment. In light of the abovementioned characteristic, it becomes plausible that uttering criticism is systematically impeded and people with doubts rather leave the company instead of staying in an environment where reservations are regarded as poisoning one's own as well as others' success (Scheibeler 2004; Sonnabend 1998).

\section{Empirical approach}

The paper is based on a single case study (Yin 2003) of the German branch of the Amway Corporation. The case study within Amway forms part of a wider research project on the organisational culture of direct selling companies in Germany which was conducted over one and a half years in three companies (Groß 2008). The starting point for this wider study was the seminal work on direct selling by Biggart (1989), conducted in the United States and including Amway as one of the oldest and biggest direct sellers.

\section{Data collection}

Contact with the company was made via its German website www.amway.de, where people who are interested in Amway can fill in a contact form. After stating her inter- 
est in the company via internet, the author was sent an email by one of the regional managers (Platinum) and called him back. Over the phone, the author presented her goal, namely learning more about the organisational culture of direct selling in Germany by doing a comparative study between three direct selling companies. After dispelling the initial concerns of the Amway contact person, namely that the goal of the author was to write a Yellow Press article, the author was invited to a regional Amway group. The regional group belongs to the biggest branch of Amway Germany. According to its founders Marianne and Max Schwarz, who have several managers on the Diamond level in their Downline, this branch is called "Schwarz-DiamondConnection" (www.schwarz-organisation.eu/de/home). The opportunity to join the regional group as a guest and as a researcher allowed the author to come into contact with interview partners as well as to experience the organisational culture and ideology of Amway via participant observation. Additionally, the author gained access to the motivational material sold by the company, such as manuals and taped speeches on how to recruit and to become successful (Schwarz/Schwarz 2001; Schwarz/Schwarz 2002).

The case study uses data triangulation (Stake 2005) and is based on the following three sources: qualitative interviews (Rubin/Rubin 1995), document analysis (Bryman/Bell 2003), and participant observation (Girtler 2001).

Within six months, the author took part in 16 weekly meetings of the SchwarzDiamond-Connection. Each meeting lasted around one and a half hours and provided the opportunity to talk with distributors before and after the actual event. During these evenings, further invitations to smaller, privately organised meetings were received and accepted. Additionally, a big semi-annual rally in Austria with approximately 1,500 people was attended. These events are designed for distributors who also may invite guests to join, i.e. mostly potential new distributors. Distributors as well as guests have to pay a $180 €$ fee for the seminar (including hotel and food, excluding drinks and transport). Observations from the above-mentioned events were logged in a research journal.

Parallel to the participant observation, twelve semi-structured face-to-face interviews with 19 successful and ambitious members including seven couples were conducted. Potential interview partners were met at the local meetings, taking a snowballing approach. Interview partners ranged in age from their early twenties until their mid fifties. One fifth of them had an academic background and three-quarters had received vocational training. Most interview partners had been members of Amway for a period between 5 and 24 years. Furthermore, the author conducted five interviews with six former distributors (one couple) and one interview with an external critic whose friends had joined the Amway Corporation. These interviews were held face to face, via phone, via e-mail, or two of the above methods.

Interviews with active and former members lasted between one and two hours on average and were recorded as well as being fully transcribed. In the analysis, distributors are quoted according to the labels they had inside the company, e.g. as an "18\%er", "21\%er", "Platinum", or "Ruby" (active distributors) or the level they had held before leaving Amway, e.g. "Former 18\%er" (see table 1). 
Table 1: Interview partners

\begin{tabular}{ll}
\hline Interview partners (partly married couples) & Quoted as ... \\
\hline Active members & "18\%er" \\
$1 \times 18 \% \mathrm{er}$ & "21\%er" \\
$1 \times 21 \% \mathrm{er}$ & "Platinum" \\
4 x Platinum & "Ruby" \\
4 x Ruby & "Emerald" \\
$2 \times$ Emerald & "Former member without level of success" \\
6 Former members & "Former 3\%er", "Former 15\%er", "Former 18\%er", "Former Ruby" \\
External critic without membership & "External critic" \\
\hline
\end{tabular}

In addition to participant observation and interviews, the case study is based on the analysis of official company documents such as the homepage of the SchwarzDiamond-Connection, ${ }^{8}$ self-help manuals (Schwarz/Schwarz 2001; Schwarz/Schwarz 2002; Schwarz/Schwarz 2005), the monthly German in-house magazine "Amagram" (Amway 2004), and international publications by the Amway founders Jay Van Andel (1998) and Rich DeVos (1994). Further document analysis includes critical websites such as "Amway: The Untold Story" or "MLM Watch". 9 These offer personal reports by former distributors and their perception of the Amway Corporation. Some former distributors have also published their own books about their experiences as Amway members in the US (Andrews 2001; Bloch 1996; Dean 1996; Scheibeler 2004) and in Germany (Sonnabend 1998).

\section{Data analysis}

The different sources of data were analysed with an inductive approach (Miles/Huberman 1994). First, the interviews were systematically coded with the help of the program atlas.ti, following the more general research question of the wider project, i.e. the organisational culture of direct selling. For Amway, the quite differing assessments of current and former distributors attracted more attention: current distributors regard their company as a just business opportunity which offers individual freedom (Conn 1977; Rampelotto/Schwarz 1999) while critics consider it to be a cultlike organisation (Bromley 1998; Butterfield 1985) which produces a high level of rather unfair financial inequality (Andrews 2001; Sonnabend 1998). In a second step, the author tried to explain these differences. One explanation could lie in the data gathering itself, namely that the interview partners who are still working for Amway were rather successful members while the group of the former distributors also included a person without a level of success as well as a " $3 \%$ er", i.e. two former members who were not successful with their Amway-business. As the interview with a former Ruby as well as the literature analysis (Scheibeler 2004; Sonnabend 1998) al-

8 Source: www.schwarz-diamond-connection.de.

9 Source: www.cs.cmu.edu/\%7Edst/Amway/AUS/ and www.mlmwatch.org/. 
lowed insights into how former successful members assess Amway after leaving the company, another explanation had to be found. Therefore the author delved more deeply into the various meanings of justice, fairness, equality etc. It became clear that loyal members ascribe the spiritual dimensions of community and meaningfulness to justice within Amway, whereas former members entirely dismiss the idea of Amway being a just company. Instead, Amway's claims to provide a socially valuable business opportunity and an encouraging community to its members are regarded as a misleading façade. The two different views of justice within Amway will be presented in the next section and provide the basis for discussing how spiritual dimensions are ascribed to justice and how these are used and misused by the company.

\section{Spirituality in Amway Germany - from a harmonious and a critical perspective}

In the US, Amway and other multi-level-marketing companies have been analysed as all-embracing and even quasi-religious organisations (Bromley 1998). Within Amway in the US, the founders Jay Van Andel and Rich DeVos are portrayed as Christian heroes who help others to live a materially successful and spiritually fulfilling life (Dean 1996). In books such as "Hope from My Heart. Ten Lessons for Life" (DeVos 2000), the founders express their commitment to God, capitalism and the United States alike - a triad that is regarded as central to the value of direct selling in the US (Biggart 1989). As "Americans have lost touch with their roots, with the qualities that made America great - individual freedom to achieve, strong families and unswerving devotion to God and country" (Bromley 1995: 142), working for Amway allows one to win back a harmonious unity between individuals, society, nation, and God.

Within Germany, Amway operates - on the surface - as a "secular" company: Open references to God or the Christian roots are hardly found. The evangelical background of the founders is little known and of the 19 interviewed Amway distributors, only one couple mentioned the Christian background of Van Andel and DeVos at all when they talked about their own commitment to the company. Furthermore, within the more than 30 live-speeches of successful distributors to which the author listened, the reference to God and Christian faith was made only once.

Nevertheless, loyal distributors present Amway as a company that offers much more than a mere job. Rather, within Amway it is emphasised that distributors can find individual fulfilment, develop personally, earn enough money to become financially independent from other income sources, and be part of a strong and supportive community at the same time. At a rally with 1,500 enthusiastic participants, a highlevel distributor, an Emerald, announced: "We all, we all need only one thing: the Amway-business".

The paper at hand focuses on one central belief, namely justice and how the spiritual dimensions of community and transcendence are connected to it. The following two parts will analyse justice from two sides. In the first, the paper will follow the harmonious understanding of organisational spirituality (Gull/Doh 2004; Marques 2005; Mitroff/Denton 1999), and loyal distributors will be quoted to show how Amway seemingly manages to satisfy individuals' spiritual needs and to increase members' commitment, loyalty, and enthusiasm. In contrast, the second part will take a critical 
approach towards organisational spirituality. Former distributors and the external critic will have a say to demonstrate why the relationship between organisational spirituality and organisational goals can be problematic. These two contrasting views will then be discussed in the paragraph thereafter to analyse how a "spiritualised" understanding of justice is used and misused by Amway.

\section{Spirituality in Amway from a harmonious perspective}

One important aspect of justice in Amway is that, like in most direct selling organisations, no qualifications are needed to become a distributor. Thus, absolutely everyone - people of all backgrounds, educational levels and personality (Brodie et al. 2002) can join and, as a matter of course, quit the organisation. This opportunity to start one's "own business" makes Amway look like an exceptionally promising organisation and loyal distributors are proud of belonging to this company: "I think it is the most democratic thing ever or the fairest thing: I don't know of anything fairer than giving people a chance to take their lives into their own hands; something which you don't get to do at a regular job!" (Ruby)

As people do not have to go through any recruitment procedures, successful distributors within the Schwarz-Diamond-Connection present Amway as not discriminating against anyone. At the local meeting as well as at the national one, single successful distributors with low social status, like a lorry driver who came as an immigrant from Russia, are highlighted as archetypes and as proof of the whole system's justice. While immigrants with little German language skill have particular difficulties on the German job market, Amway is presented as a chance for anybody. Because "we share the chances. I have the chance and if I keep it for myself, I won't proceed in the business. And if I share it, the others proceed, too." (Platinum) Whereas other organisations ask for qualifications, here everybody may start doing business. Whereas other organisations provide access only to a small amount of carefully selected members, Amway is presented as community which anybody may enter.

The belief in Amway's justice is supported by the low cost of entry (Amway 2004). While starting other businesses - like opening a shop - is too expensive for many people, the application fee for Amway is presented as almost non-existent. In this line of argument, a manager explained the ethical side of the business: "In my opinion the business is ethical because you don't need an initial investment. You have this application fee of 40 Euro and some pennies. And it's a three month try-out! ... It's just laughable." (Emerald) As everybody may enter, Amway is seen as a solution to the high unemployment rate in Germany as well as an individual chance to succeed financially: "In times of high unemployment rates it is the most effective way to determine your own income" (Current distributor ${ }^{10}$ ). According to loyal distributors, Amway offers a win-win-situation to organisational members, to the company, and to society: it allows individual ambition, to earn money, is a chance to earn money, and provides equal opportunity to all social classes. All aspects together make clear that

10 The source is a letter to the editor on the following website: www.dtp-sonnabend.de/BUCH.HTM, accessed on 6/22/2006. 
"Amway scores much higher than all the rest. Because it is simply a just, a just system!" (Ruby).

Additionally, the equal chances within the company are not regarded as egalitarian in a negative sense, i.e. that everybody receives the same amount of money independent of his or her effort. Rather, Amway has a performance-linked payment system and thus people who work harder can earn more. "So, that's what's great about it ... when someone [in our line] starts below us, he could even be the one hundredth below us, ... if he worked more than we did, he could also earn more money." (Ruby) While other organisations have unfair and obscure compensation schemes or are even infiltrated by favouritism, the provision system of Amway treats everybody exactly the same, as distributors are paid according to their turnover and the turnover of their Downline.

The range of dreams that can be fulfilled via Amway is broad. According to the company ideology, the system allows individuals to choose how much effort they want to spend, how far they want to take their success, and which dreams they want to fulfil via their Amway business. Distributors' dreams may range from earning an additional 200 Euro/month to becoming a Diamond, the manager level that is praised most within the company. The publications sold at the local and national meetings suggest that being a Diamond provides a monthly commission around 17,800 Euro (Schwarz/Schwarz 2001). According to the videos shown at the national seminar, the Diamond and even higher levels provide the financial opportunity to realise such outlandish individual dreams as long exclusive holidays, one's own villa with swimming pool and sauna, Rolex watches, or expensive cars.

Because members can earn more money by recruiting others into their group, distributors have a strong financial incentive to "help" others build up their Amway business. Recruiting becomes a means for building up one's own business, but also to contribute to societal welfare. Loyal distributors emphasise how much they appreciate working with others and "sharing" their own experiences with new members. It is "one of the nicest things I can imagine! To work with others ... and to show others what is important and how they themselves can become [financially and personally] free" through their business (Ruby).

To summarise the view of loyal distributors, they praise their company as a means for satisfying their need to belong to a (just) community and their wish to have a meaningful job (Polley et al. 2005). The ideal of justice within Amway provides the feeling of being treated in a fair way and having a fair chance to succeed individually. The ideal of fair treatment is combined with the chance to be rewarded based on one's own effort. According to loyal members, Amway allows the fulfilment of individual wishes to succeed with the societal ideal of fairness in relation to others. In comparison to a rather unfair business world, membership in Amway is portrayed as a chance to achieve individual fulfilment and to help others. Furthermore, it is regarded as a societal solution for high unemployment rates.

When linking these empirical statements back to the harmonious literature on organisational spirituality (Mitroff/Denton 1999), Amway offers spiritual fulfilment by satisfying the need for belonging and meaningful work (Polley et al. 2005). While 
many members leave the company within the first year (Juth-Gavasso 1985), ${ }^{11}$ the remaining distributors seem to form a strong community (Bromley 1998; Pratt 2000a; Pratt 2000b). The active distributors reported to the author that they prefer to socialise with other "Amwaynians" - a label that loyal distributors use (sometimes jokingly) to distinguish themselves from outsiders. "I've realised that my earlier friends ..., that I've lost nothing with losing them; deep in my heart, I always wanted to be in another world." (21\%)

The second characteristic of spirituality, i.e. the meaningfulness of work, differs between Amway Germany and Amway in the US. As described above, in the US the company has a strong focus on serving God and the Nation via being a self-employed entrepreneur in direct selling (Biggart 1989). The American founders make deliberate references to their Christian faith (DeVos 2000) and also other distributors talk about their faith publicly in the national context (Dean 1996). The religious affiliation of the founders or distributors as well as the ideal of "serving the Nation" are almost irrelevant for the German context. Instead, justice is a central belief that lifts the selling of products and the recruiting of friends and family members to a higher moral ground: by offering a fair business opportunity, members help other people and support the development of a fair society, while reaching individual goals and dreams. Although justice is not linked to God or a Christian denomination, Amway Germany also promises a harmonious unity, namely between individuals, the organisation and society.

\section{Spirituality in Amway from a critical perspective}

The belief in Amway as a fair business opportunity for everybody is in contrast to the inequality that is inherent in the Amway system itself. The average gross sale of distributors in Germany is an estimated $113 € /$ month. ${ }^{12}$ Combining this estimated monthly turnover with an official overview of possible provisions (see e.g. Schwarz/Schwarz 2001) allows an estimation of how many distributors can earn a living with their Amway business as portrayed in table 2: to reach the level of a Platinum, on average 176 people in one's own Downline are needed. Thus, only one out of 177 can reach this level and therefore only a share of $0.57 \%$ of all members can be on this level with a gross provision between 2.200 and $3.000 € /$ month. The level of success praised most within the company, the Diamond-level, is said to gain a monthly gross provision of around 17,800 $€$ (Schwarz/Schwarz 2001: 26). However, this level can by estimation only be reached by one member out of 4,478 as a distributor needs 4,477 "average members" in his or her Downline. Accordingly, only an approximated $0.02 \%$ of all members can achieve this level (Groß 2008: 193).

11 There are no data available for Germany.

12 The calculation considers 85.000 self-employed members in Germany with a total turnover of 119 Mio. $€$ in 2003/2004 (source: www.amivo.de/press_room01.html, accessed on $11 / 27 / 2006$ ). Considering that members pay an annual fee (estimated 4 Mio. $€ /$ year), the monthly turnover per member is $113 €$. These figures are estimations as the numbers published by the Amway Corporation do not give closer insights how the turnover has been created (via product sales to distributors or via other services). 
Table 2: Estimation on share of successful distributors in Amway

\begin{tabular}{lccc}
\hline Level of success & Monthly gross provision in Euro & Members needed in Downline & Possible share of level \\
\hline Platinum & $\sim 3,000$ & 176 & 1 out of 177, i.e. $\sim 0.57 \%$ \\
Diamond & $\sim 17,800$ & 4,477 & 1 out of 4,478, i.e. $\sim 0.02 \%$ \\
\hline
\end{tabular}

Amway's strong emphasis on providing a fair and equal chance to everybody also stands in contrast to the many aspects that make success more likely such as the market situation, personal character traits, and individuals' social, cultural, and financial capital (Bourdieu 1983). A former distributor explains five of the many conditions that helped people to succeed: "1. Many started when the company was founded in Germany. Obviously the chance for success was much higher than 30 years later. 2. Many were self-employed before. Thus, they already had customers and work experience. 3 . Many had a professional qualification. 4. Many had savings to invest. 5. Market demand is different [today] because of time, place, and human needs" (Former distributor without level of success). Moreover, individual character traits and personal gifts such as rhetorical abilities and humour help to do financially well. Such traits are not widespread but special, just as one of the early successful distributors who was a "golden boy to love and to trust, and with a strong entrepreneurial and competent charisma" (Former Ruby). Last but not least, the emphasis on equality does not take into account that financial, social, and cultural capital (Bourdieu 1983) can be regarded as very helpful for selling products and recruiting others into the system. From the participant observation it became clear that the only people in the regional group who had managed to reach the level of Ruby throughout the last five years were two couples who each consisted of a practicing physician and a spouse doing the Amway business. As the physicians seem to offer Amway's vitamin products via their offices and to advise patients to go to their spouses for further consult about Amway, they have a broad customer base. Additionally, they have a relatively high social status from which to convince others to buy products and to join the company. One spouse of a physician gave the author an example how they motivate people in their Downline. The following quote is about a carpenter whom they had invited to their nice home with a swimming pool the evening before the interview: "[H]e had lost sight of his goal a little bit. ... We invited them yesterday evening, we had a little champagne, we ate some scampi, and we showed a little bit of quality of life" (Ruby).

The Amway Corporation, not the profession as a physician, is presented as offering such a high quality of life: a nice home with a swimming pool, eating scampi, and drinking champagne. From a critical perspective on spirituality in organisations, this implies that the ideal of justice and fairness is used to veil existing inequality, i.e. between the chances of a physician and the ones of a carpenter to recruit members and to sell products.

Nevertheless, the low costs of entering the company and the equal application of the commission system are used by the Amway Corporation to put the responsibility of success on the individual distributors. As preconditions for success are the same, according to successful distributors' view, failure is presented as a personal malfunction, a lack of individual effort, and a sign of a deficient belief in one's own strengths 
and in the Amway system. As an official handbook for distributors explains, failing is due to individuals: "Every willing and hard-working person can be successful in this business ... We, as people, are subject to different influences and motivations; thus, we do not function equally well all the time. However, a good system always works!" (Schwarz/Schwarz 2001: 2) Here, the notion of justice is used by the corporation and its high-level distributors to neglect organisational responsibility for the chances members have of generating income via their Amway business. Rather, the responsibility of Amway and of such high-level distributors as the Schwarz-DiamondConnection is to provide an "education system" that consists of motivational tapes, videos, books, and tickets for semi-annual rallies such as half-day "Kick-offs" with 7.000 people or 2 -day-seminars with around 1,500 people.

A further way in which the ideal of justice is used to mask a problematic aspect of the company is the propagation of distributor recruitment as "helping others". As a Diamond put it in a weekly meeting "People outside are waiting for our business". Nevertheless, recruiting friends, relatives, and acquaintances to one's own Downline implies making money off their efforts - a behaviour that is "socially and psychologically unacceptable to most people in our society" (Bloch 1996: 18). Whereas emotional bonds within the company are strong (Lan 2002), former distributors complain about how little their Amway friends cared about them after they left the business (Scheibeler 2004; Sonnabend 1998): "Right at the beginning you're confronted with love, i.e. attention by Amwaynians. You get the impression that people are really interested in you as a person. ... That's simply not true. It is only a means to bind you to the group. That's why you're dumped really quickly when you leave them. That's deliberately misguiding" (former distributor without level of success). Presenting Amway as a way to help others and as a just company in an unfair world supports the belief of distributors in the morality of the company and of their own behaviour. It allows distributors to "relieve themselves of the feeling of being phoney, alien, and insincere" (Lan 2002: 175).

Recruiting others is not only transcended as "helping others" but it is also encouraged by presenting Amway as a fair (and realistic) business opportunity to reach individual goals - ranging from some additional earnings to becoming rich or buying a summer cottage. This argumentation implies that every adult is a potentially new distributor and new members are asked to make a register of all people they know: family, relatives, friends, acquaintances, service providers (one's hairdresser, butcher, or physician), class mates etc. (Schwarz/Schwarz 2002). Based on this register, the recruiter teaches the new distributor how to call these people and to make appointments to present the Amway business - or at least to sell some products (Schwarz/Schwarz 1993).

Although such appointments are made to earn money, they are presented as a kind of pleasant leisure activity with friends. A distributor explains: "Doing this business is no labour. ... of course you have to do something, so in some aspect it is work but it depends on how you see it: is it really hard work to go to my friends and explain to them how the business works? Or am I looking forward to meeting them and helping them so that they proceed? ... It is fun, there's nothing nicer than having coffee together and talking about the business with people" $(18 \% \mathrm{er})$. Within this quote but 
also at meetings, the "work-character" is downplayed and the social aspects, such as meeting others, drinking coffee, and reaching goals together, are emphasised. However, although loyal members may feel part of a strong and fair community, the data presented above show a different picture: only a few people earn money and friendship seems to end when people leave Amway.

\section{Discussion: mis/use of spiritual elements}

The goal of the paper is to provide empirical insight into how spirituality can be employed by an organisation and to discuss why this can be problematic. In addition to the empirical data presented above, it is important to understand first what spirituality, i.e. community and transcendence (Polley et al. 2005), means within this company and second, why it can be argued that spirituality supports the organisational goals of the Amway Corporation.

In relation to the first aspect, it is relevant to take into account that Amway Germany neither explicitly refers to a religious denomination nor propagates a "workplace spirituality programme". Spirituality, i.e. the spiritual dimensions of community and transcendence, is linked to other organisational elements, namely to the value of justice and to rules that are regarded as just, such as the commission system. Therefore, Amway does not simply have a low entry barrier for new distributors because the company wants to attract as many distributors as possible. Rather, the spiritual dimensions lift up the company to a fair business opportunity and to a contribution to a better society. Amway itself is presented as a community in which people help each other - instead of earning commission on each others' work, in this community, people who help others are rewarded financially, emotionally, and morally for their good deeds. In line with these propagated high qualities of Amway, individual members are provided with the chance to earn money, to live their own dreams, to grow personally, and to contribute to social welfare at the same time.

Although it was not the goal of the paper to measure the direct influence of these beliefs on the company's success, it is argued that they contribute to the commitment and loyalty of distributors. Similar to what has been observed in the US (Bromley 1998; Pratt 2000a), within Germany members who prolong their membership after the first year tend to stay even in the absence of financial success. The staying power of these members not only produces product turnover and a steady stream of new members for the company (as distributors recruit new members), but also generates income for Uplines such as the Schwarz-Diamond-Connection. The latter sells motivational material and offers seminars for distributors who have reached a certain level of success as well as national rallies for distributors on all levels of success. Exact numbers are lacking, but in 2005 there were at least 22 seminars for distributors on all levels (Schwarz/May 2005) which were attended by approximately 1,500 participants each and cost 180 Euro per person (including hotel and food). According to this information, these seminars created an estimated turnover of around 6 million Euros worth of fees - not including the sales of the recorded speeches (40 Euro per seminar), books and beverages.

Based on the descriptions above, table 3 (below in the text) shows the more detailed interlinks between the "spiritualised" understanding of justice (left column), 
how this contributes to organisational goals (middle column), and why this is a misuse (right column).

The first row is about the notion that Amway is fair because everybody can start the business as entry barriers are low, i.e. low entrance fee and no prerequisites such as previous job experience or a particular education. These arguments help the company to propagate the notion that every adult is a potential distributor and that members should not hesitate to offer the Amway business to others. Such a view is problematic as the average turnover shows that being a distributor does not imply having a business opportunity, i.e. earning money. It can be assumed that the entry barriers are low because Amway wants to gain new members who buy products and motivational material. The focus on the low entry barriers also helps to divert attention from the problem that is described in the second row. Amway propagates that it offers the opportunity to everybody to reach individual goals, i.e. earning a little additional money or becoming affluent. Such a belief helps the company to present itself as offering a fair chance to reach individual success according to one's own wishes. The problematic point about this argumentation is that success in Amway not only depends on individuals' goals and efforts, but on a huge range of other criteria. Aspects such as a charming, enthusiastic personality, a high social status as well as having started many years ago, have helped distributors to belong to the rather small group of financially successful members. The third row is about the fact that members are treated equally by the commission system. It allows Amway to present itself as a company working on fair principles and to divert attention away from other forms of inequality that coexist in this company. To the latter belongs the commission system which, via its structure, regulates the success of an individual by making this success dependent on the size and the activity of the distributors below him or her. As high-level distributors earn commissions off all members below them, it is more attractive to have joined the company earlier than later. The fourth row is about the belief that Amway is a fair and just company because recruiting others and helping them to become successful is emotionally and financially rewarded. This view legitimises earning money off others as morally good and transcends the recruitment of others as "helping" them. It is problematic because it veils that recruiting others and helping them to succeed serves the personal interest in building up one's own group and earning off its activities. Additionally, it legitimises the socially tainted behaviour of making money off personal relationships (Bloch 1996). The last row refers to the ideal that Amway is a fair community in a rather unfair business world. Here, the company is portrayed as adding a high value to society and as being an example of good corporate behaviour. This view is problematic in light of the amount and intensity of criticism that has been evoked by the company (Andrews 2001; Dean 1996; Scheibeler 2004; Sonnabend 1998). Additionally, Amway presents itself as a fair and "perfect" company and in turn puts the responsibility of failure on the level of individual distributors. 
Table 3: Overview of mis/use of justice and its spiritual dimensions

Amway's justice

... is presented as
... everybody has the
chance to enter Amway
as entry barriers are low
... distributors have a fair
chance to reach their in-
dividual goals
in a fair way because the
commission system is
applied equally
... distributors are emo-
tionally and financially
rewarded for helping oth-
ers to succeed

\section{Conclusion}

The spiritual elements that are propagated within Amway Germany serve organisational interests as they support members' efforts to recruit and to commit themselves to their Amway business. At the same time, Amway seems to satisfy members' wish for meaningful work and binds distributors together in a strong community. On the surface, Amway seems to offer the win-win-situation for employees and companies that is in line with the harmonious strand of literature on organisational spirituality (Gull/Doh 2004; Kolodinsky et al. 2008; Marques 2005; Mitroff/Denton 1999). However, the above analysis also shows how spirituality is employed by Amway to portray the company as a fair, special, and exemplary business opportunity and to morally lift up Amway members and their activities - whereas the vast majority of members do not and cannot earn enough money to live from their "business".

This article wants to contribute to a critical perspective on spirituality. While existing critical studies are mainly based on analyses of popular and academic discourses on organisational spirituality (Bell/Taylor 2003; Heelas 1992; Nadesan 1999), the study at hand focuses on the organisational level. It shows how spirituality can be employed by an organisation. Within Amway, spirituality is not bound to a deliberate "spirituality change programme" or a religious denomination. Instead, Amway "spiritualises" organisational elements to present the company and its activities as legitimate 
or even particularly valuable. Within Amway, this takes place in two ways: first, the company emphasises the spiritual quality of justice and thereby introduces a spiritual element to its organisational culture - Amway presents itself as an organisation that offers a chance to everybody and treats people in a fair manner; second, elements of the organisational structure are extolled: Amway lifts up the commission system and the rules for entry as means to contribute to a better society.

The paper argues that this "spiritualisation" of organisational elements can help to better understand how workplace spirituality can be used and misused by organisations. Although the Amway Corporation is certainly an uncommon company as members are self-employed distributors, the described mechanisms are independent of Amway's particular characteristics as a direct selling organisation. "Spiritualisation" means that organisational elements are presented as having a transcendent meaning or as supporting a community feeling within a company (Bell/Taylor 2003). Accordingly, the paper wants to support the need to challenge (Nadesan 1999) the basic idea of the harmonious strand of literature on workplace spirituality, i.e. that spirituality and profit-making have an unproblematic relationship with each other. Whether both can form a win-win-situation is an open empirical question that cannot be answered globally but depends on the respective organisation. Accordingly, the mere claim for more spirituality in the workplace is to be questioned as it ignores the potential problems connected with workplace spirituality (Polley et al. 2005).

The paper at hand has focused on one problematic aspect, namely how organisational spirituality can be misused to deny the basic conflict of interest between organizational and individual goals, i.e. to spiritually cleanse the organization and the activities of its members. In conclusion, the paper wants to point out three aspects of misuse:

- First, spirituality can be used and misused to mislead members about the work task, i.e. the character of the work they have to do as well as the material basis of work. Doing meaningful work has become important for many employees (Kuhn et al. 2008; Lair et al. 2008) and it has been reported that managers rank "making money" lower than having an interesting task where one can realise one's full potential as a person and is associated with a respected organisation (Mitroff/Denton 1999). Nevertheless, most employees need to earn their living via their job and work is not only inspiring and interesting but can also include boring, uninspiring routine tasks as well as problematic, stressful, and even annoying aspects. Thus, in line with other critical empirical studies on strong organisational cultures (Kunda 1992) and organisational ideology (Potterfield 1999), one way to misuse spirituality is to divert attention away from the unattractive or even problematic aspects of work tasks as well as from the material side of working, i.e. income and career opportunities (Sullivan 2006). Instead, work is presented as selffulfilling (Nadesan 1999; Bell/Taylor 2003) and people are motivated to work "happily" more and harder as has been reported in companies as various as startups during the "New Economy" or in ecclesiastical health organisations where employees earn less than in privately run ones. 
- Second, spirituality can be used to provide a misleading picture of the organisation and what it can provide to its members. As it has been analysed in relation with other organisational culture (Kunda 1992), shared values, common beliefs and organisation-wide propagated norms can be used to create strong commitment and to propagate strong personal bonds amongst members and from members to their company. Strong organisational cultures have been criticised for colonising individuals' personal lives (Willmott 1993) and the case study in Amway provides empirical evidence that spirituality has the same potential to do so (Nadesan 1999; Pina e Cunha et al. 2006). Aside from the social risk of creating "a world of spiritual newspeak", following Willmott's (1983) critique on strong organisational cultures, organisations themselves have to take into account that propagating spiritual ideals can backfire on them. When employees realise that mission statements are marketing tools rather than an expression of a lived culture, or when promises are not kept - e.g. when people in times of crisis are laid off in a blunt manner - the loss of confidence felt can be particularly high.

- Third, spiritual values can be misused to create a wrong impression about the societal role and value of an organisation. Via transcending work tasks, organisational structures and goals, companies can present themselves as "good corporate citizens" (Fombrun/Rindova 2000). Although empirical data is lacking, spirituality can be regarded as a further means to building up a strong reputation (e.g. The Body Shop). Such a reputation may be justified as organisations are different in how well they treat their members. However, it is necessary to take into account that spirituality can also help lift up a socially tainted company (Kreiner et al. 2006) to a seemingly moral higher ground.

Even though some Amway members may have found individual fulfilment via the company, the empirical evidence given here shows that an increased interest in organisational spirituality does not necessarily lead to a win-win-situation for employees and their employer. Spiritual fulfilment is an individual goal and organisations have their own goals. Whether both can go hand in hand, simply co-exist or are in opposition to each other is an open empirical question. The harmonious strand of literature on organisational spirituality has provided a series of studies to show that spirituality and organisational profit making have an unproblematic relationship with each other (Gull/Doh 2004; Marques 2005; Mitroff/Denton 1999). The case study presented in this article shows a problematic interlink between both. One former Amway distributor characterised the talking about Amway as a just and fair company as a "fairy tale hour" (Former distributor, 18\%er) - others regard it as far worse, namely as a scam (Fitzpatrick/Reynolds 1997).

\section{References}

Alvesson, M./Willmott, H. (2002): Identity Regulation as Organizational Control: Producing the Appropriate Individual. In: Journal of Management Studies, 39(5): 619-644.

Amway GmbH (Ed.) (2004): Geschäftspartnerantrag und Erstanforderung. Amway GmbH.

Andrews, J. (2001): Ain't It Great? A Look Inside Amway. Bloomington: 1st Books Library.

Ashforth, B. E./Vaidyanath, D. (2002): Work Organizations as Secular Religions. In: Journal of Management Inquiry, 11(4): 359-370. 
Bell, E./Taylor, S. (2003): The Elevation of Work: Pastoral Power and the New Age Work Ethic. In: Organization, 10(2): 329-349.

Bellah, R. N. (1975): The Broken Covenant. American Civil Religion in Time of Trial. Chicago: The University of Chicago Press.

Biggart, N. W. (1989): Charismatic Capitalism. Direct Selling Organizations in America. Chicago: The University of Chicago Press.

Bloch, B. (1996): Multilevel marketing: what's the catch? In: Journal of Consumer Marketing, 13(4): 1824.

Bolman, L. G./Deal, T. E. (1995): Leading with soul: An uncommon journey of spirit. San Francisco: Jossey-Bass.

Bourdieu, P. (1983): Ökonomisches Kapital - Kulturelles Kapital - Soziales Kapital. In: P. Bourdieu (Ed.): Die verborgenen Mechanismen der Macht. Hamburg: VSA-Verlag: 49-80.

Brodie, S./Stanworth, J./Wotruba, T. (2002): Comparisons of Salespeople in Multilevel vs. Single Level Direct Selling Organizations. In: Journal of Personal Selling/Sales Management, 12(2): 67-75.

Bromley, D. G. (1995): Quasi-religious corporations. A new integration of religion and capitalism? In: R. H. Roberts (Ed.): Religion and the transformation of capitalism. Comparative approaches. London: Routledge: 135-160.

Bromley, D. G. (1998): Transformative Movements and Quasi-Religious Corporations. The Case of Amway. In: N. J. Demerath/P. D. Hall/T. Schmitt/R. H. Williams (Eds.): Sacred Companies. Organizational Aspects of Religion and Religious Aspects of Organizations. New York: Oxford University Press: 349-363.

Brown, R. B. (2003): Organizational Spirituality: The Sceptic's Version. In: Organization, 10 (2): 393-400.

Bryman, A./Bell, E. (2003): Business research methods. Oxford: Oxford University Press.

Butterfield, S. (1985): Amway. The Cult of Free Enterprise. Boston: South End Press.

Conn, C. P. (1977): The Possible Dream. A candid look at Amway. New York: Berkley Books.

Croft, R./Woodruffe, H. (1996): Network Marketing: The Ultimate in International Distribution. In: Journal of Marketing Management, 12: 201-214.

Daniels, D./Franz, R. S./Wong, K. (2000): A Classroom with a worldview: Making spiritual assumptions explicit in management education. In: Journal of Management Education, 24 (5): 540-561.

Dean, A. (1996): Consumed by Success. Reaching the top and finding God wasn't there ... Mukilteo: WinePress Publishing.

DeVos, R. (1994): Compassionate Capitalism: People Helping People Help Themselves. La Vergne: Ingram Plume Books.

DeVos, R. (2000): Hope From My Heart. Ten Lessons for Life. Nashville: Thomas Nelson.

Fitzpatrick, R. L./Reynolds, J. K. (1997): False Profits. Seeking Financial and Spiritual Deliverance in Multi-Level-Marketing and Pyramid Schemes. Charlotte: Herald Press.

Fombrun, C. J./Rindova, V. P. (2000): The Road to Transparency: Reputation Management at Royal Dutch/ Shell. In: M. Schultz/M. J. Hatch/M. H. Larsen (Eds.): The Expressive Organisation. Linking Identity, Reputation, and the Corporate Brand. Oxford: Oxford University Press: 77-96.

Franz, R. S./Wong, K. L. (2005): Spirituality and Management: A Wider Lens. A Comment on D. Steingard's "Spiritually-Informed Management". In: Journal of Management Inquiry, 14 (3): 247-250.

Girtler, R. (2001): Methoden der Feldforschung. Wien, Köln, Weimar: Böhlau Verlag.

Groß, C. (2008): Multi-Level-Marketing - Identität und Ideologie im Network-Marketing. Wiesbaden: VS.

Gull, G. A./Doh, J. (2004): The "Transmutation" of the Organization: Toward a More Spiritual Workplace. In: Journal of Management Inquiry, 13 (2): 128-139.

Heelas, P. (1992): The Sacralization of the Self and New Age Capitalism. In: N. Abercrombie/A. Warde (Eds.): Social Change in Contemporary Britain. Cambridge: Polity Press: 139-166.

Jones, L. B. (1995): Jesus CEO: Using Ancient Wisdom for Visionary Leadership. New York: Hyperion Books.

Juth-Gavasso, C. L. (1985): Organizational Deviance in the Direct Selling Industry: A Case Study of the Amway Corporation. Ann Arbor: University Microfilms International. 
Kaufmann, F.-X. (1989): Religion und Moderne. Sozialwissenschaftliche Perspektiven. Tübingen: J.C.B. Mohr.

Kolodinsky, R. W./Giacalone, R. A./Jurkiewich, C. L. (2008): Workplace Values and Outcomes: Exploring Personal, Organizational, and Interactive Workplace Spirituality. In: Journal of Business Ethics, 81: 465-480.

Kreiner, G. E./Ashforth, B. E./Sluss, D. M. (2006): Identity Dynamics in Occupational Dirty Work: Integrating Social Identity and System Justification Perspectives. In: Organization Science, 17 (5): 619636.

Kuhn, T./Golden, A. G./Jorgenson, J./Buzzanell, P. M./Berkelaar, B. L./Kisselburgh, L. G./Kleinman, S./Cruz, D. (2008): Cultural Discourses and Discoursive Resources for Meaning/ful Work. Constructing and Disrupting Identities in Contemporary Capitalism. In: Management Communication Quarterly, 22 (1): 162-171.

Kunda, G. (1992): Culture. Control and Commitment in a High-Tech Corporation. Philadelphia: Temple University Press.

Lair, D. J./Shenoy, S./McClellan, J. G./McGuire, T. (2008): The Politics of Meaning/ful Work. Navigating the Tensions of Narcissism and Condescension While Finding Meaning in Work. In: Management Communication Quarterly, 22 (1): 172-180.

Lan, P.-C. (2002): Networking Capitalism: Network Construction and Control Effects In Direct Selling. In: The Sociological Quarterly, 43 (2): 165-184.

Marques, J. F. (2005): The spiritual worker. An examination of the ripple effect that enhances quality of life in- and outside the work environment. In: Journal of Management Development, 25 (9): 884895.

Miles, M. B./Huberman, M. A. (1994): Qualitative Data Analysis. An Expanded Sourcebook. Thousand Oaks: Sage.

Mitroff, I. I. (2003): Do Not Promote Religion under the Guise of Spirituality. In: Organization, 10 (2): 375-382.

Mitroff, I. I./Denton, E. A. (1999): A Study of Spirituality in the Workplace. In: Sloan Management Review, Summer: 83-92.

Nadesan, M. H. (1999): The Discourses of Corporate Spiritualism and Evangelical Capitalism. In: Management Communication Quarterly, 13 (1): 3-42.

Pina e Cunha, M./Rego, A./D'Oliveira, T. (2006): Organizational Spiritualities. An Ideology-Based Typology. In: Business/Society, 45 (2): 211-234.

Polley, D./Vora, J./SubbaNarasimha, P. N. (2005): Paying the devil his due: limits and liabilities of workplace spirituality. In: The International Journal of Organizational Analysis, 13 (1): 50-63.

Potterfield, T. A. (1999): The Business of Employee Empowerment. Democracy and Ideology in the Workplace. Westport: Quorum Books.

Pratt, M. G. (2000a): Building an Ideological Fortress: The Role of Spirituality, Encapsulation and Sensemaking. In: Studies in Cultures, Organizations and Societies, 6: 35-69.

Pratt, M. G. (2000b): The Good, the Bad, and the Ambivalent: Managing Identification among Amway Distributors. In: Administrative Science Quarterly, 45 (3): 456-493.

Rampelotto, L./Schwarz, M. (1999): Das Schwarz-System. Schwarz Books.

Rose, N. (1990): Governing the Soul: The Shaping of the Private Self. London: Routledge.

Rubin, H. J./Rubin, I. S. (1995): Qualitative Interviewing. The Art of Hearing Data. Thousand Oaks: Sage.

Scheibeler, E. N. (2004): Merchants of Deception. An Insider's Look at the Worldwide, Systematic Conspiracy of Lies that is Amway/Quixtar and Their Motivational Organization. Available: www.merchantsofdeception.com (July 12, 2005): Eric N. Scheibeler.

Schwarz, M./May, M. (2005): Wir starten durch. Aufzeichnung einer Seminarrede von Mona May und Max Schwarz. Langenmosen: Marianne und Max Schwarz GmbH/Co. Vertriebsförderungs KG.

Schwarz, M./Schwarz, M. E. (1993): Tips zur Terminabsprache. Aufbauhilfe 4. Marianne und Max Schwarz.

Schwarz, M./Schwarz, M. E. (2001): Mein Weg zum Kronenbotschafter. Langenmosen: Marianne und Max Schwarz GmbH/Co. Vertriebsförderungs KG. 
Schwarz, M./Schwarz, M. E. (2002): Der Erfolgsweg. Langenmosen: Marianne und Max Schwarz $\mathrm{GmbH} / \mathrm{Co}$. Vertriebsförderungs KG.

Schwarz, M./Schwarz, M. E. (2005): Die Säulen des Erfolges. Arbeits- und Weiterbildungsseminar Frühjahr 2005. Schwarz, Marianne und Max GmbH/Co. Vertriebsförderungs KG.

Sonnabend, U. (1998): Der geliehene Traum. In der Seifenblase zum Kronenbotschafter. München: ZeitGeist Forum.

Stake, R. (2005): Qualitative Case Studies. In: N. K. Denzin/Y. S. Lincoln (Eds.): The Sage handbook of qualitative research. Thousand Oaks: Sage: 443-466.

Steingard, D. S. (2005): Spiritually-Informed Management Theory. Toward Profound Possibilities for Inquiry and Transformation. In: Journal of Management Inquiry, 14 (3): 227-241.

Sullivan, S. C. (2006): The Work-Faith Connection for Low-Income Mothers: A Research Note. In: Sociology of Religion, 67 (1): 99-108.

Van Andel, J. (1998): An Enterprising Life. An Autobiography. New York: HarperCollins.

Volf, M. (1991): Work in the spirit: Toward a theology of work. New York: Oxford University Press.

Weber, M. (1920/1988): Die protestantischen Sekten und der Geist des Kapitalismus. Gesammelte Aufsätze zur Religionssoziologie I. Tübingen: J.C.B. Mohr: 207-236.

Willmott, H. (1993): Strength is Ignorance; Slavery is Freedom: Managing Culture in Modern Organizations. In: Journal of Management Studies, 30 (4): 515-552.

Wippermann, C. (1998): Religion, Identität und Lebensführung. Opladen: Leske + Budrich.

Yin, R. K. (2003): Case Study Research. Design and Methods. Thousand Oaks: Sage. 